Удк 617-001-031.72-056.52-07-08-039

DOI 10.11603/2414-4533.2017.3.8019

СС. Д. ХIMIЧ, ${ }^{1}$ О. М. ЧЕMЕРИС ${ }^{2}$

Вінницький національний медичний університет імені М. І. Пирогова ${ }^{1}$

Львівський національний медичний університет імені Данила Галицького ${ }^{2}$

\title{
Нестандартні ситуації в процесі діагностики та лікування постраждалих із політравмою на тлі ожиріння
}

\begin{abstract}
Мета роботи: визначити проблемні питання діагностики, надання медичної допомоги та лікування постраждалих із політравмою залежно від ступеня ожиріння.

Матеріали і методи. Клінічний матеріал отримали завдяки спостереженню за 51 пацієнтом із політравмою, яких лікували в хірургічному відділені Комунальної 8-ї міської клінічної лікарні м. Львова протягом 2009-2017 рр.

Результати досліджень та їх обговорення. Конвенційні методи діагностики при закритій торакальній та абдомінальній травмі були достатніми у пацієнтів з нормальною масою тіла. У постраждалих із ожирінням достовірність даних об'єктивного обстеження знижувалося залежно від ступеня ожиріння, що вимагало від хірурга діяти нестандартно, широко застосовувати інвазійні методики там, де, звалося б, не потрібно жодних інтервенцій.

У ході вибору лікувальної тактики у постраждалих із ожирінням також відслідковувалися певні особливості, що, з одного боку, можна пояснити тим, що навіть при відносно однакових механізмах травми, особи з ожирінням отримують тяжчі пошкодження, тобто тяжкість ушкодження прямо пропорційна ступеню ожиріння; проте з іншого боку компенсаторними властивостями організму в людей з нормальною масою тіла та початковими проявами ожиріння, у яких вдавалося одноетапно інтраопераційно як зупинити кровотечу, так і ліквідувати усі інтраабдомінальні пошкодження.

Вибір методів діагностики і лікування при політравмі необхідно здійснювати з урахуванням значення індексу маси тіла постраждалих.
\end{abstract}

Ключові слова: ожиріння; політравма; діагностика; лікування.

Постановка проблеми і аналіз останніх досліджень та публікацій. Питання клінічної діагностики, лікувальних підходів із наступним попередженням розвитку ускладнень у процесі лікування травматичної хвороби, спричиненої поєднаною травмою тіла, й надалі залишаються проблемними. Наприклад, за даними Л. Н. Анкин (2002 р.), Я. Л. Заруцького (2006 р.) лише приблизно у 20 - 25 \% випадків вдається встановити правильний діагноз за даними об'єктивного клінічного обстеження. Однією з причин такої ситуації $є$ посттравматичні неврологічні розлади, які зумовлюють нетипову симптоматику при закритих торакальних і абдомінальних пошкодженнях, а також сп’яніння різної етіології [1, 2, 3].

Проте ще одним, чи не найбільш проблемним контингентом, про який нечасто згадують, складають постраждали з політравмою на тлі ожиріння, особливо II-III ступеня, у яких діагностична цінність клінічних та інструментальних методик значно знижена, а лікувальні підходи часто відрізняються порівняно із хворими із нормальною масою тіла [7, 9]. Лікування таких постраждалих - це завжди виклик для ургентного хірурга, оскільки при верифікації домінуючого та інших пошкоджень він повинен враховувати характер травми залежно від типу ожиріння, наявність супутньої патології та розвиток типових ускладнень. Значний відсоток діагностичних помилок у постраждалих із ожирін- ням на фоні шоку, черепно-мозкової травми, супутніх захворювань, або сп'яніння різної етіології, різноманіття характеру ускладнень, котрі, як правило, виникають при отриманні травм у людей із ожиріння, потребує певних спеціальних алгоритмів та плану надання медичної допомоги з урахуванням вагових критеріїв постраждалих $[4,5]$. Саме тому, у зв'язку з особливостями клінічних проявів пошкоджень та з метою підвищення ефективності лікувально-діагностичних заходів у політравмрованих постраждалих із ожирінням різного ступеня, необхідно проводити більш ретельне клінічне обстеження із використанням максимально можливого спектра діагностичних методик $[6,8]$.

Особливості перебігу травматичної хвороби у людей із ожирінням пов'язують із недостатньою активністю компенсаторних можливостей організму, пов'язаних з численними хронічними захворюваннями серцево-судинної, легеневої, нервової систем, а також функціональних розладів організму, що призводить до зниження можливого якісного результату в лікуванні цієї групи постраждалих.

Мета роботи: визначити проблемні питання діагностики, надання медичної допомоги та лікування постраждалих із політравмою залежно від ступеня ожиріння.

Матеріали і методи. Клінічний матеріал отримали завдяки спостереженню за 51 пацієн- 
том із політравмою, яких лікували в хірургічному відділені Комунальної 8 міської клінічної лікарні м. Львова протягом 2009-2017 рр. 3 них 38 (74,5 \%) постраждалих були із поєднаною тупою травмою грудної клітки, тупою травмою живота та закритою черепно-мозковою травмою. Переломи кісток таза чи кінцівок були у 13 (25,5 \%) хворих. Вік пацієнтів коливався в межах від 18 до 84 років (середній вік - $(47,2 \pm 1,4)$ року), чоловіків було - 36 (70,5 \%), жінок 15 (29,5 \%), осіб працездатного віку - 41 (80,4 \%).

Залежно від значення індексу маси тіла (IMT) усіх постраждалих було розділено на три клінічні групи. До першої групи увійшли 21 (41,2 \%) хворий із нормальною масою тіла (IMT $\geq 24,9$ кг/ $\mathrm{M}^{2}$ ), до другої - 19 (37,3 \%) постраждалих із зайвою масою тіла та ожирінням I ст. (IMT $=26,2-34,2$ кг $/ \mathrm{M}^{2}$ ) та до третьої - 11(21,5 \%) травмованих із ожирінням II - III ст. (IMT = 35,3 - 41,9 кг $/ \mathrm{M}^{2}$ ).

Усі пацієнти були госпіталізовані у проміжку від 20 хв до 1,5 год від моменту отримання травми, що склало в середньому $(43,1 \pm 1,4)$ хв. За обставинами отримання травми переважали дорожньо-транспортні пригоди (водій, пасажир або пішохід) - 28 осіб (54,9 \%), у 14 (27,5 \%) випадків - падіння з висоти 3 - 6 метрів, у 9 (17,6 \%) - побиття іншими особами.

Обстеження проводили згідно з локальними протоколами, які включали аналіз скарг, анамнезу захворювання та життя, клінічної картини на догоспітальному етапі та стаціонарі, особливостей травмуючого чинника. У пацієнтів із ожирінням діапазон загальноприйнятих доступних методик розширювали залежно від значення IMT.

Результати досліджень та їх обговорення. Після проведеного клінічного обстеження пацієнтів черговими лікарями стаціонару, хірургом визначався перелік діагностичних медотик залежно від тяжкості стану постраждалих. Так, усіх “гемодинамічно” стабільних хворих (39; 76,5 \%) скеровували для проведення додаткових інструментальних методів дослідження, а “гемодинамічно” нестабільних (12; 23,5 \%) пацієнтів відразу подавали в операційну.

У першій підгрупі хворих проводили лабораторні дослідження, рентгенографію органів грудної клітки (ОГК), черепа, таза, кінцівок, ультразвукову діагностику (УЗД) органів черевної порожнини (ОЧП) чи за методикою FAST, а при необхідності комп’ютерну томографію (КT). Застосування інвазивних методик (торакоцентез, лапароцентез) проводили у випадках недостатньої інформативності попередніх обстежень або при невідповідності характеру виявлених ушкоджень за допомогою інструментальних методів діагностики до тяжкості загального стану пацієнта.

У другій підгрупі пацієнтів, як правило, відразу виконували торакоцентез при закритій торакальній травмі з метою швидкої діагностики та усунення гемо-пневмотораксу, а при закритій абдомінальній травмі - лапароцентез з наступною оцінкою характеру отриманого інтраабдомінального вмісту.

Проте у процесі реалізації алгоритму обстеження у постраждалих часто виникали нестандартні моменти, пов'язані із діагностичною здатністю різних методик залежно від IMT, особливо у пацієнтів із II-III ступенем ожиріння (III клінічна група).

Як виявилось, конвенційні методи діагностики були достатніми у пацієнтів I клінічної групи. Так, для верифікації діагнозу при закритій торакальній та абдомінальній травмі, окрім даних об'єктивного обстеження, лабораторних досліджень, інформативною була рентгенографія ОГК, УЗД ОЧП, що у 18 (85,7 \%; р > 0,05) випадків дозволило виявити усі пошкодження. У 3 (14,3 \%) з метою уточнення діагнозу проводили КТ обстеження ОГК, після якого констатовано двобічні неускладнені забої легень без порушення цілісності реберного каркасу.

У ІІ клінічній групі ступінь достовірності даних об'єктивного обстеження знижувався, заключення інструментальних методів не завжди дозволяли виявити усі пошкодження, причому у 4 $(21,1 \%$; р > 0,05) випадках це зумовило необхідність використовувати лапароцентез, що, в свою чергу, дало можливість діагностувати пошкодження печінки (2; 50 \%) і тонкої кишки (2; 50 \%).

Контраверсійною була ситуація у III клінічній групі, де не тільки суттєво знижувалася чутливість практично усіх діагностичних методик ( $>$ > 0,04), але й зменшувався їх можливий діапазон використання, а саме проведення КT, що безпосередньо корелювало із значенням IMT. Такі ситуації змушували хірурга діяти нестандартно, широко застосовувати інвазійні методики там, де, звалося б, не потрібно жодних інтервенцій. Зокрема, у 6 (63,6 \%) випадках лише за допомогою торакоцентезу верифіковано плевро-легеневі ускладнення (гемо-пневмоторакс), а зниження чутливості та специфічності УЗД ( $s=67,8$ та $f=78,3$ \% (p > 0,03) формувало підгруття для виконання лапароцентезу в усіх постраждалих із ожирінням II-III ст. (100 \%; p > 0,01), що кінцево дозволяло діагностувати внутрішньочеревну кровотечу.

У ході вибору лікувальної тактики також відслідковувалися певні особливості хірургічної тактики залежно від IMT. Так, із 12 гемодинамічно нестабільних пацієнтів 9 (75 \%) були із ожи- 
рінням II-III ст, що, з одного боку, можна пояснити тим, що навіть при відносно однакових механізмах травми особи з ожирінням отримують тяжчі пошкодження, тобто тяжкість ушкодження $€$ прямо пропорційна ступеню ожиріння; проте 3 іншого - компенсаторними властивостями організму у людей з нормальною масою тіла та початковими проявами ожирінням, у яких вдавалося одноетапно інтраопераційно як зупинити кровотечу, так і ліквідувати усі інтраабдомінальні пошкодження.

Серед пацієнтів у вкрай тяжкому стані III клінічної групи домінували пошкодження паренхіматозних органів у 8 (66,7 \%), з них печінки - у 6 (50,0 \%), селезінки - 1 (8,3 \%), постраждалого розриви селезінки і печінки у 1 (8,3 \%) і лише у 1 (8,3 \%) постраждалого були пошкодження тонкої кишки. Враховуючи дані об'єктивних вітальних параметрів життєдіяльності, в усіх випадках застосовано тактику хірургічного лікування “damage control”. Первинний етап хірургічної допомоги полягав у виконанні пекінгу черевної порожнини у 4 (33,3 \%) випадків, спленектомію і пекінг у 2 (16,7 \%), накладанні судинних затискачів і пекінг також у 2 (16,7 \%) із формуванням лапаростоми шляхом накладання “швів-бантиків”.

Складність діагностики пошкоджень при закритій абдомінальній і торакальній травмі у постраждалих із політравмою достатньою мірою залежить від супутнього ожиріння. Значну увагу слід приділяти оцінці клінічної симптоматики, проте враховуючи значення IMT пацієнта у кожному конкретному випадку. Скарги постраждалих на тлі ожиріння, як правило, є малоінформативними, оскільки поріг больової чутливості у цієї групи пацієнтів значно знижений, особливо при IIIII ст. ожиріння. Також не завжди інтенсивність болю у постраждалих із ожирінням II-III ст. залежить від кількості крові в черевній порожнині, тому кількісне вираження гемоперитонеуму не завжди викликає сильніший біль порівняно із хворими з нормальної масою тіла $[7,9,10]$.

Застосування фізикальних способів діагностики при закритій травмі живота також практично не дає жодної інформації, оскільки віддиференціювати характер перкуторного звуку у хворих IIIII ст. ожиріння навіть у випадках масивного ге-

\section{СПИСОК ЛІТЕРАТУРИ}

1. Анкин Л. Н. Иерархия лечения повреждений при политравме / Л. Н. Анкин, Н. Л. Анкин // Збірник тез I Всеукраїнської науково-практичної конференції з міжнародною участю “Політравма - сучасна концепція надання медичної допомоги”. K., 2002. - C. 9-10. моперитонеуму є не можливим, і здійснювати аускультативну оцінку перистальтичних шумів.

Використання деяких рутинних конвенційних інструментальних методів діагностики у постраждалих із ожиріння II-III ст. при політравмі не завжди мають високу інформативність у процесі оцінки тяжкості пошкоджень, тому у даної групи постраждалих слід розширювати показання до застосування інтервенційних методик, які мають найвищу чутливість та специфічність $[9,10]$.

У контексті визначення особливостей хірургічного лікування людей із II-III ступенем ожирінням слід дотримуватися тактики програмованих етапних релапаротомій.

Таким чином, слід зазначити, що постраждалим із ожирінням потрібно приділяти надзвичайно велику увагу під час первинного огляду і клінічного обстеження. Важливим залишається кожна деталь у механізмі та характері травми, яка дозволить запідозрити будь-яке пошкодження, адже при загальному задовільному стані у постраждалого при політравмі з ожирінням можуть буди надзвичайно значні замасковані ушкодження. Слід пам'ятати, що у пацієнтів на тлі ожиріння значно більші ризики тупої травми грудної клітки $з$ переломами реберного каркасу, як правило, ускладнені гемо-пневмораксом [1,7].

Висновки. 1. Вибір методів діагностики при політравмі необхідно здійснювати з урахуванням значення IMT постраждалих.

2. У пацієнтів із II-III ст. ожиріння діагностична цінність традиційних діагностичних способів $€$ нижчою порівняно із хворими з нормальною масою тіла, тому у даній групі пацієнтів слід розширювати показання до застосування інтервенційних методик.

3. Програмовані релапаротомії слід розглядати як один із основних методів комплексного лікування людей із II-III ступенем ожиріння.

Перспективи подальших досліджень полягають у вивченні діагностичної цінності та придатності клінічних, інструментальних і спеціальних методів обстеження, а також у розпрацюванні окремих протоколів надання медичної допомоги постраждалим з політравмою залежно від IMT.

2. Заруцький Я. Л. Клінічно-організаційні основи та принципи діагностики і хірургічного лікування постраждалих з травматичною хворобою: автореф. дис. на здобуття наук. ступеня докт. мед. наук: спец. 14.01.03 “Хірургія” / Я. Л. Заруцький. - Київ, 2004. - 32 с. 
3. Заруцкий Я. Л. Некоторые нерешенные проблемы лечения пострадавших с политравмой / Я. Л. Заруцкий, Л. Н. Анкин // Проблеми військової охорони здоров'я: зб. наук. праць Укр. військ.-медичн. академії. - К., 2006. - Вип. 17. - С. 43-53. 4. Павловський М. П. Травматичні ушкодження паренхімних органів черевної порожнини / М. П. Павловський, І. Р. Трутяк, І. Д. Герич // Одеський медичний журнал. - 2004. - № 4 (84). - С. 60-62.

5. Петкау В. В. Хірургічне лікування постраждалих із закритою поєднаною абдомінальною травмою в гострому періоді травматичної хвороби: автореф. дис. на здобуття наук. ступеня канд. мед. наук. : спец. 14.01.03 “Хірургія” / В. В. Петкау. - Київ. - 2009. - 20 с.

6. Результаты лечения закрытых повреждений органов брюшной полости и забрюшинного пространства / Э. Римша,

\section{REFERENCES}

1. Ankin, L.N., \& Ankin, N.L. (2002). Iyerarkhiya lecheniya povrezhdeniy pri politravme [Hierarchy of the treatment of injuries in polytrauma]. Collection of theses and the AllUkrainian scientific and practical conference with international participation "Polytrauma - Contemporary Concept of Provision of Medical Aid”. Kyiv [in Russian].

2. Zarutskyi, Ya.L. (2003). Kliniko-orhanizatsiini osnovy ta pryntsypy diahnostyky i khirurhichnoho likuvannia postrazhdalykh z travmatychnoiu khvoroboiu [Clinical-organizational bases and principles of diagnostics and surgical treatment of victims with traumatic illness]. Doctor's thesis. Kyiv [in Ukrainian].

3. Zarutskiy, Ya.L. \& Ankin, L.N. (2006). Nekotorye nereshenye problemy lecheniya postradavshykh s politravmoy [Some unresolved problems of treatment of victims with polytrauma]. Problemy viiskovoi okhorony zdorovia: zb. nauk. prats Ukr. viisk.medychn. akademii - Problems of Military Health: Collection of Scientific Works of Ukrainian Military Medical Academy (17), 43-53 [in Russian].

4. Pavlovskyi, M.P., Trutiak, I.R., \& Herych, I.D. (2004). Travmatychni ushkodzhennia parenkhimichnuykh orhaniv cherevnoi porozhnyny [Traumatic damage to the parenchymal organs of the abdominal cavity]. Odeskyi medychnyi zhurnal Odesa Medical Journal, 4 (84), 60-62 [in Ukrainian].
И. Шршас, В. Катилюс [и др.] // Актуальные вопросы травматологии: материалы каунасского пленума хирургов Литовской ССР. - Каунас : Швиеса. -1973. - С. 82-84.

7. Grant P. Emergency management of the morbidly obese / P. Grant, M. Newcombe // Emerg. Med. - 2004. - Vol. 16(4). - P. 309-317.

8. Incidence and clinical pattern of the abdominal compartment syndrome after "'damage-control" laparotomy in 311 patients with severe abdominal and/or pelvic trauma / W. Ertel, A. Oberholzer, A. Platz [et al.] // Crit. Care Med. - 2000. - № 28. -P. 1747-1753. 9. Oberg B. Obesity: an anaesthetic challenge / B. Oberg, T. Poulsen // Acta. Anaesthesiol. Scand. - 1996. - Vol. 40(2). - P. 191-200.

10. Shaftan G. Diagnosis of acute abdominal trauma. In: principles and practice of trauma care / G. Shaftan // Baltimore. - 1982. P. 105-116.
5. Petkau, V.V. (2009). Khirurhichne likuvannia postrazdalykh iz zakrytoiu poiednanoiu abdominalnoiu travmoiu $\mathrm{v}$ hostromu periodi travmatychnoi khvoroby [Surgical treatment of victims with closed combined abdominal trauma in acute period of traumatic illness]. Candidate's thesis. Kyiv [in Ukrainian].

6. (1973). Resultaty lecheniya zakrytykh povrezhdeniy organov bryushnoy polosti i zabryushynnogo prostranstva [Results of treatment of closed injuries of the abdominal cavity and retroperitoneal space]. Aktualnye voprosy travmatologii: Materialy kaunasskogo plenuma khirurgov Litovskoy SSR Topical issues of traumatology: Materials of the Kaunas plenum of surgeons of the Lithuanian SSR [in Russian].

7. Grant, P., \& Newcombe, M. (2004). Emergency management of the morbidly obese. Emerg. Med. 6 (4), 309-317.

8. Ertel, W., Oberholzer, A., \& Platz, A. (2000). Incidence and clinical pattern of the abdominal compartment syndrome after "damage-control" laparotomy in 311 patients with severe abdominal and/or pelvic trauma. Crit. Care Med., (28), 17471753.

9. Oberg, B., \& Poulsen, T. (1996). Obesity: an anaesthetic challenge. Acta. Anaesthesiol. Scand., 40 (2), 191-200.

10. Shaftan G. (1982). Diagnosis of acute abdominal trauma. In: Principles and practice of trauma care. Baltimore, 105-116.

\section{S. D. $\mathrm{KHIMICH},{ }^{1}$ O. M. CHEMERYS ${ }^{2}$}

M. Pyrohov Vinnytsia National Medical University ${ }^{1}$,

Danylo Halytskyi Lviv National Medical University ${ }^{2}$

\section{NON-STANDARD SITUATIONS IN DIAGNOSTIC PROGESS AND TREATMENT OF OBESE PATIENTS CAUSED BY POLYTRAUMA}

The aim of the work: identifying problematic issues of diagnosis, medical care and treatment of polytrauma patients depending on the degree of obesity.

Materials and Methods. Clinical material is based on the observation of 51 polytrauma in patients treated in the Surgical Department of the Lviv Municipal Clinical City Hospital No. 8 in the period of 2009-2017.

Results and Discussion. Conventional diagnostic methods for blunt thoracic and abdominal trauma were sufficient in patients with normal body mass. In obese patients, the reliability of the objective survey data decreased, depending on the degree of obesity, which forced the surgeon to act non-standard, widely apply invasive techniques where it would be called no intervention.

During the selection of treatment tactics, obese patients also traced certain features that, on the one hand, can be explained by the fact that even with relatively similar mechanisms of injury, obese individuals are more severely damaged, that is, the severity of the injury 


\section{ОРИГІНАЛЬНІ ДОСЛІДЖЕННЯ}

is directly proportional to the degree of obesity. But on another hand, compensatory properties of the body in people with normal body mass and initial manifestations of obesity, which managed one-stage intraoperatively to stop the bleeding, and to eliminate all intraabdominal damage.

Conclusions. Forming the diagnosis and treatment methods in polytrauma patients must be carried out taking into account the body mass index.

Key words: obesity; polytrauma; diagnostic; treatment.

\section{С. Д. ХИМИЧ ${ }^{1}$ О. М. ЧЕМЕРИС ${ }^{2}$}

Винницкий национальный медицинский университет имени Н. И. Пирогова ${ }^{1}$ Львовский национальный медицинский университет имени Данила Галицкого²

\section{НЕСТАНДАРТНЫЕ СИТУАЦИИ В ПРОЦЕССЕ ДИАГНОСТИКИ И ЛЕЧЕНИЯ ПОСТРАДАВШИХ С ПО.ЛТРРВМОЙ НА ФОНЕ ОЖИРЕНИЯ}

Цель работы: определить проблемные вопросы диагностики, оказания медицинской помощи и лечения пострадавших с политравмой в зависимости от степени ожирения.

Материалы и методы. Клинический материал основан на базе наблюдения за 51 пациентом с политравмой, которые лечились в хирургическом отделении Коммунальной 8 городской клинической больницы г. Львова в течение 2009-2017 гг.

Результаты исследований и их обсуждение. Конвенционные методы диагностики при закрытой торакальной и абдоминальной травме были достаточными у пациентов с нормальной массой тела. У пострадавших с ожирением достоверность данных объективного обследования снижалась в зависимости от степени ожирения, заставляли хирурга действовать нестандартно, широко применять инвазивные методики там, где, казалось бы, не нужно никаких интервенций.

В ходе выбора лечебной тактики у пострадавших с ожирением также отслеживались определенные особенности, что, с одной стороны, можно объяснить тем, что даже при относительно одинаковых механизмах травмы, лица с ожирением получают более тяжелые повреждения, то есть тяжесть повреждения прямо пропорциональна степени ожирения; однако с другой стороны компенсаторными свойствами организма у людей с нормальной массой тела и начальными проявлениями ожирения, в которых удавалось одноэтапно интраоперационно как остановить кровотечение, так и ликвидировать все интраабдоминальные повреждения.

Выбор методов диагностики и лечения при политравме необходимо осуществлять с учетом значения индекса массы тела пострадавших.

Ключевые слова: ожирение; политравма; диагностика; лечение. 